\title{
Developing Learning Set with STEM-PBL Approach to Mathematics Connection Ability and Student's Learning Motivation
}

\author{
Indra K. Wijayanti ${ }^{1, *}$ Agus M. Abadi ${ }^{2}$ \\ ${ }^{1}$ Graduate Programme of Mathematics Education, Faculty of Mathematics and Natural Science, Yogyakarta State \\ University, Indonesia \\ ${ }^{2}$ Mathematics Education Department, Yogyakarta State University, Indonesia \\ ${ }^{*}$ Corresponding author. Email: indrakusumawijayanti@gmail.com
}

\begin{abstract}
This study aims to produce and describe the development process and quality of learning set with the STEM-PBL approach. The development model in this study was adopted from Plomp model, it is preliminary research, development, and evaluation. The learning set developed include lesson plan and student's worksheet for Statistics material in class VIII using the STEM PBL approach. The quality of development can be measured by its validity, practicality, and effectiveness. The learning set with STEM-PBL that was delevoped is valid, it was found that the warriors got very good criteria. Practically besause in the observations of the learning implementation, it is known that learning is carried out by $90 \%$ (teacher activities) and $96 \%$ (student activities) so that learning is carried out properly according to plan. Meanwhile, the results of teacher assessments and student responses were good.The learning set is effective because the results of the student's mathematical connection ability test at high category with the acquisition of an average value of 14.2, the students learning motivation at high category with an average score of 81.7. The results of this study, it can be concluded that the mathematics learning set developed is feasible to use.
\end{abstract}

Keywords: STEM-Education PBL, Connection Mathematics, Student's Motivation.

\section{INTRODUCTION}

Globalization has entered a new era called the industrial revolution era 4.0. Indonesia is one of the countries participating in global development. The Industrial Revolution 4.0 has fundamentally changed the way humans think, live and relate to one another. This era will change various activities. This change resulted in the loss of many types of work [1]. This shows that every human being must have his existence in facing global competition by preparing mentally and skills that can face competition. Humans are required to have collaborative abilities, critical and creative thinking, and be able to communicate effectively to face challenges of the current era [2].

This kind of ability can be developed through learning mathematics. There is a need for students to have ability to connect mathematically [3]. The present urgency condition of student is not good in mathematics connection. Students who master mathematical concepts are not automatically good at connecting mathematics without a mathematical connection. Students must learn and remember too many separate mathematical concepts and procedures $[3,4]$. The ability of students to understand concepts is not only proven by knowing or remembering some of the concepts that have been studied but also being able to reexpress in another form that is easy to understand, provide data interpretation, and be able to apply concepts to other fields that are suitable for cognitive structures [5]. Several studies have shown that the mathematical connection ability of junior high school students is low [6-10].

In addition to cognitive abilities in the form of mathematical connection, student assessment is carried out based on the affective aspect. Motivation plays an important the development of student potential. There is a positive relationship between mathematical connection ability and learning motivation [11]. However, in reality in the field, student' s motivation toward mathematics is classified as low, this is indicated by the fact that students tend not to be serious in teaching and learning activities, talking with friends or being no respond when they are asked [12].

Developing a learning method to improve student's connection ability and learning motivation is unavoidable, it requires a learning method to develop these abilities. The solution offered is a problem-based learning method with a STEM-Education learning approach. This integration is expected to be the key to success for developing a country, especially in the context of competing for career development or supporting 21st-century skills. The problem-based learning method is characterized by making the problem 
the starting point of the learning process as a tools of practicing problem understanding skills. The PBL approach is more effective in increasing student achievement, mathematical connection skills, and selfesteem [7]. STEM integrated education combines some or all of the four disciplines for science, technology, engineering, and mathematics with real-world problems [13]. Based on global needs that demand the creation of competent humans in various fields, several studies show that STEM connects four disciplines, they are science, technology, engineering, and mathematics that are suitable for use in 2013 curriculum learning. Integrate STEM in teaching and learning science in primary and secondary schools shows that learning can increase achievement and interest in learning [14].

Acourding to theory, The Science, Technology, Engineering, and Mathematics (STEM) Education learning approach can improve student connection skills and learning motivation. Based on observations made by researches, it was found that the teacher had not developed learning set for the STEM-Education learning approach, the problem-based learning method. Therefore, this research aims to produce mathematics learning set for VIII grade junior high school students in Statistics material with the STEM-Education approach to problem-based learning methods that are oriented towards mathematical connection abilities and student learning motivation. The quality of the tools developed is based on validity, practicality, and effectiveness.

\section{METHOD}

Three stages are used in this research procedure. First, the preliminary research, in this initial research stage, needs analysis, and situation analysis is carried out. An important element in this stage is the collecting information, defining the problem, and planning followup activities based on the problems found. Researchers do observations as a form of realization of this stage. Second, development stage (development or prototyping phase), the activities in this second stage is design solutions to problems that have been defined in the initial research. The results in this stage are documents as a form of solution from problems found in the initial research stage. Furthermore, in this stage, the design of the first version; called prototype, is made. In this stage, an alternative design is formulated to be developed related to these problems. Then, the product development process is also carried out at this stage. The third stage is the assessment phase in which implementation and evaluation are carried out to improve the product being developed. The implementation in this stage is product testing for grade VIII students. Product testings were held in April-May 2020 at SMP Negeri 3 Bulu, Temanggung, Central Java. The test subjects in this research were 13 students of VIII grade SMP Negeri 3 Bulu. The subjects of this study used 13 volunteer respondents or more than
$50 \%$ of the minimum number of students in one class group.

The educational development model according to Plomp was chosen because this model is considered relatively simple and practical [15]. The product development procedure in this research is presented through the chart in the following figure 1 .
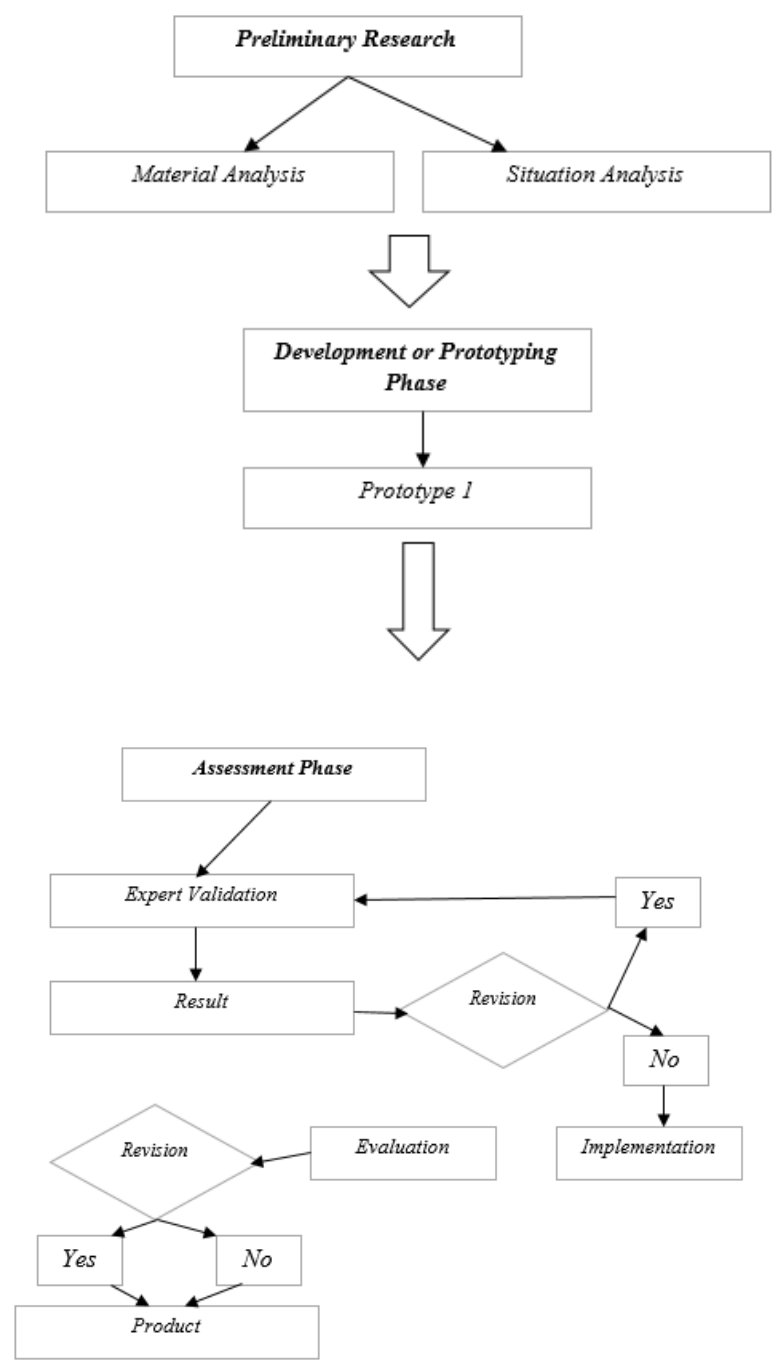

Figure 1 The procedure of learning set development

The data analysis process in this research includes an assessment of the validity, effectiveness, and practicality of the learning set developed based on expert judgment [15]. Data analysis used guidelines according to Azwar [16] to determine the quality classification into a scale of 5 as in the Table 1 below. 
Table 1. Quality classification

\begin{tabular}{|l|l|}
\hline Interval Mean Score & Classification \\
\hline $\bar{x}>\bar{X}_{t}+1.5 s b_{i}$ & $\begin{array}{l}\text { Very good/very } \\
\text { high }\end{array}$ \\
\hline $\bar{X}_{t}+0.5 s b_{i}<\bar{x} \leq \bar{X}_{t}+1.5 s b_{i}$ & Good/high \\
\hline $\bar{X}_{t}-0.5 s b_{i}<\bar{x} \leq \bar{X}_{t}+0.5 s b_{i}$ & Enough \\
\hline $\bar{X}_{t}-1.5 s b_{i}<\bar{x} \leq \bar{X}_{t}-0.5 s b_{i}$ & Bad/low \\
\hline $\bar{x} \leq \bar{X}_{t}-1.5$ & Very bad/very low \\
\hline $\begin{array}{l}\bar{X}_{t}=\frac{\max \text { score }+ \text { min score }}{2} ; s b_{i}=\frac{\max \text { score-min score }}{6} ; \bar{x}: \\
\text { empiric mean score }\end{array}$ \\
\hline
\end{tabular}

Furthermore, the classifications of validation quality, effectiveness (mathematical connection ability and student learning motivation), and teacher assessment and student responses are shown in Table 2, Table 3, and Table 4. [16]

Table 2. Classification of quality validity assessment

\begin{tabular}{|l|l|}
\hline Interval Mean Score & Classification \\
\hline $\bar{x}>132$ & Very good \\
\hline $110<\bar{x} \leq 132$ & Good \\
\hline $88<\bar{x} \leq 110$ & Enough \\
\hline $66<\bar{x} \leq 88$ & Bad \\
\hline $\bar{x} \leq 66$ & Very bad \\
\hline
\end{tabular}

The quality of learning set is considered valid and feasible as learning set if they meet the minimum classification good.

Table 3. Classification of effectiveness quality assessment

\begin{tabular}{|c|c|c|}
\hline Aspect & $\begin{array}{l}\text { Interval mean } \\
\text { score }\end{array}$ & Classification \\
\hline \multirow{5}{*}{$\begin{array}{l}\text { Mathematics } \\
\text { connection } \\
\text { ability }\end{array}$} & $\bar{x}>14.25$ & Very high \\
\hline & $11.09<\bar{x} \leq 14.25$ & High \\
\hline & $7.91<\bar{x} \leq 11.09$ & Enough \\
\hline & $4.75<\bar{x} \leq 7.91$ & Low \\
\hline & $\bar{x} \leq 4.75$ & Very low \\
\hline \multirow{5}{*}{$\begin{array}{l}\text { student's } \\
\text { learning } \\
\text { motivation }\end{array}$} & $\bar{x}>79.5$ & Very high \\
\hline & $66.5<\bar{x} \leq 79.5$ & High \\
\hline & $53.5<\bar{x} \leq 66.5$ & Enough \\
\hline & $40.5<\bar{x} \leq 53.5$ & Low \\
\hline & $\bar{x} \leq 40.5$ & Very low \\
\hline
\end{tabular}

Qualitative assessment of the effectiveness aspect uses the guidelines in Table 3. The quality of learning set is considered effective if the mathematical connection ability and student motivation are in the high minimum category. The average value of the students' mathematical connection ability is more than 11.09 from maximum score is 19 , while the average value of student learning motivation is more than 66.5. In assessment the quality of practicality, the assessment guidelines in Table 4 are

Table 4. Assessment of practicality

\begin{tabular}{|l|l|l|}
\hline Aspect & $\begin{array}{l}\text { Interval mean } \\
\text { score }\end{array}$ & Classification \\
\hline \multirow{4}{*}{$\begin{array}{l}\text { Assessment } \\
\text { teacher }\end{array}$} & $\bar{x}>52$ & Very good \\
\cline { 2 - 3 } & $43.34<\bar{x} \leq 52$ & Good \\
\cline { 2 - 3 } & $34.66<\bar{x} \leq 43.34$ & Enough \\
\cline { 2 - 3 } & $26<\bar{x} \leq 34.66$ & Bad \\
\cline { 2 - 3 } Response & $\bar{x} \leq 26$ & Very bad \\
\hline \multirow{4}{*}{ Student } & $\bar{x}>64$ & Very good \\
\cline { 2 - 3 } & $53.34<\bar{x} \leq 64$ & Good \\
\cline { 2 - 3 } & $42.66<\bar{x} \leq 53.34$ & Enough \\
\cline { 2 - 3 } & $32<\bar{x} \leq 42.66$ & Bad \\
\cline { 2 - 3 } & $\bar{x} \leq 32$ & Very bad \\
\hline
\end{tabular}

The quality of learning set is considered to meet the quality of practicality as a learning set if it is included in the minimum good classification both from teacher assessments and student response questionnaires.

Furthermore, qualitative classification is used to determine the percentage of learning implementation which is presented in Table 5

Table 5. Qualitative classification of learning implementation

\begin{tabular}{|l|l|}
\hline Interval mean score & Classification \\
\hline $80 \%<t \leq 100 \%$ & Very good \\
\hline $60 \%<t \leq 80 \%$ & Good \\
\hline $40 \%<t \leq 60 \%$ & Enough \\
\hline $20 \%<t \leq 40 \%$ & Bad \\
\hline$t \leq 20 \%$ & Very bad \\
\hline
\end{tabular}

Note : $\mathrm{t}$ : mean score of learning implementation

Based on the results of the qualification of the implementation of learning, the quality of learning equipment is considered practical if it meets the minimum classification good or $t>60 \%$. The products developed in this study are learning set that include lesson plans and student worksheets for Statistics grade VIII Semester 2 using the PBL STEM learning approach 
that is oriented towards mathematical connection abilities and student learning motivation.

Furthermore, to determine whether there is a relationship between mathematical connection ability and student learning motivation, we used correlation analysis with the Pearson correlation test. The Pearson correlation test was carried out to see the direction of the linear relationship between two variables and the degree of strength of the relationship between the two variables. If the significance value is less than 0.05 then the two variables are declared to have correlation, whereas if the significance value is more than 0.05 then the two variables are declared uncorrelated.

\section{RESULT AND DISCUSSION}

Preliminary stage of this research consists of measuring of mathematical connection ability, knowing the learning motivation, and observing the use of learning set in the field. These steps were held about 8 months, December 2018 - July 2019. Twenty three students were given problems related to circle topic. This topic has two mathematical connection indicators, connection between mathematics and daily life (MDL) and connection between mathematical concepts (MC). Mathematical connection ability in the indicator of applying the relationship between concepts or topics in mathematics is classified as low with a score of 150 or $43.47 \%$ of the total score of 345 . If the percentage was converted into a score produces an average score of 43.47 so that it falls into the low category. While the indicators applying mathematical concepts to solve real problems are classified as low with a score of 98 or $53.26 \%$ from a total score of 184 . If the percentage was converted into a score produces an average score of 53.26 so that it falls into the low categoryFrom their answer, we can conclude that the mathematical connection ability of students was low [6].

Furthermore, a student learning motivation questionnaire was given to 60 of grade VIII students. Based on the questionnaire given through the survey, students' learning motivation was low. A further survey was conducted according to the results of previous research. This survey aims to count out how many teachers who modify learning set to improve mathematical connection ability and learning motivation of students. Based on the survey, learning set that facilitate improving mathematical connection abilities are still rare. Furthermore, a review of supporting theories is conducted to improve the quality of learning found in previous studies. The STEM approach in the context of real-world problems can increase learning motivation and increase student interest, learning achievement, and persistence [17]. Research conducted by Blotnick [18] reveals that STEM can improve student collaboration skills, problem-solving abilities, and mathematical connection skills. STEM is also able to increase self-efficacy and student motivation. From this review, efforts were made to apply the STEM-Education approach with the Problem Based Learning (PBL) learning model which has the characteristics of project work in some of its learning activities, linking mathematical concepts with concepts in other fields, connecting mathematics with real-life problems, and carrying out activities. by utilizing technology. The application of this approach can be done in the learning process.

Learning is a mental or psychic activity which is an active process in building knowledge, taking place in the interaction of individuals with learning sources, which results in several changes $[19,20]$. The learning set developed in this study are following the opinions of these experts. Through learning set with the STEM approach to the PBL learning model, students carry out activities to build their knowledge actively through worksheet to facilitate developing mathematical connection skills and student learning motivation. Products developed to consist of statistical learning set which include Lesson Plan and Student Activity Sheets. Furthermore, to complement the product, a syllabus, answer keys for student activities, and learning outcomes tests (tests of mathematical connection ability and student learning motivation questionnaire) were also compiled. Learning set in the form of lesson plans can help teachers to organize learning activities that can facilitate mathematical connection skills. Worksheet of learning set can be used as a student learning resource that is used to facilitate students' mathematical connection skills.

The lesson plan and worksheet developed to consist of four lesson plans and worksheet for statistics for VIII grade at even semester. The characteristics of the lesson plans developed are lesson plans based on the 2013 curriculum, compiled based on basic competencies and achievement indicators, activities are arranged based on PBL stages with the STEM-Education approach, learning uses real problems and projects, lesson plans are integrated with student's worksheet, there are practice questions to facilitate students to develop abilities mathematical connections and the existence of daily reflection activities to facilitate students to develop student learning motivation. The characteristics of the developed student's worksheet are that the problems presented are real problems that can be solved with a project or experiment, then the data in the experiment are used to introduce the statistical material. Student's worksheet is prepared using coherent instructions for easy use by students.

Development products in the form of learning set and instruments in this study have been assessed by expert lecturers and mathematics teachers. The results of the assessment of expert lecturers and mathematics teachers can be seen in the Table 6 below. 
Table 6. Result validation

\begin{tabular}{|l|l|l|}
\hline Component & Score & Category \\
\hline Lesson Plan & 152.6 & Very Good \\
\hline $\begin{array}{l}\text { Student's } \\
\text { worksheet }\end{array}$ & 143.3 & Very Good \\
\hline
\end{tabular}

Based on the table above, the lesson plan gets an average score of 152.6 and is in the very good category. Based on the results of this assessment, it can be concluded that the lesson plan is suitable for use in mathematics learning and has been developed based on the appropriate lesson plan development procedure. lesson plan is said to be feasible based on several aspects, namely the suitability of learning with the STEM PBL model approach, content feasibility, linguistic feasibility, and presentation feasibility. While the results of the student's worksheet assessment in terms of material and appearance aspects get an average score of 143.3 with a very good classification. Therefore, the developed student's worksheet has fulfilled the aspects of material coverage suitability, product suitability with a learning orientation, namely mathematical connection ability and student learning motivation, feasibility of STEM PBL approach, presentation feasibility, linguistic feasibility, and usefulness. Based on the overall assessment, it can be concluded that student's worksheet has met the criteria to become teaching materials that can be used in mathematics learning in schools.

The assessment instrument which includes a mathematical connection ability test and a developed learning motivation questionnaire is also declared valid, which means it is suitable for use with revisions according to expert input. Matters that need to be revised include redaction, writing errors, the suitability of the grid with the questions, and answer keys. The revised assessment instrument based on the results of the assessment and input from the validator is declared to have met the validity aspect. This is following the opinion of Fitriyani and Sugiman [21] which states that a product is said to be valid because it has gone through an expert validation process until valid results are obtained.

Furthermore, student's worksheet statistical material with the STEM PBL model approach that has been expertly validated and revised then tested on a limited basis to 3 students. Students are asked to read and provide comments and suggestions about the developed worksheet and fill out a readability guide sheet. Based on the results of limited trials, necessary improvements were made to improve the quality of the product development. These improvements include redaction, ineffective introductory sentences to activities, and writing errors.

The next trial is a trial in learning mathematics in class. Researchers conducted trials by teaching directly to students and accompanied by research assistants. The research assistant is in charge of observing the use of the product during learning, it is known that product development can facilitate students in various activities that facilitate the development of students' mathematical connection skills, students are guided to solve the problems contained in the student's worksheet. So that students can connect mathematics with real-world problems or problems in other fields. The daily reflection activity at the end of the lesson went well. The daily reflection sheet on the student's worksheet contains about the lessons that day and the targets to be achieved. When learning in class students look active and enthusiastic in learning. The variety of activities in learning such as making catapults makes students feel motivated. Through giving rewards, students are allowed to respect themselves.

This field trial resulted in data being analyzed to determine the practicality and effectiveness of the learning set being developed. Practicality can be seen from the observation sheet for the feasibility of learning, the teacher and student assessment sheets, while the effectiveness can be seen from the test results of the mathematical connection ability and student learning motivation. The practicality of the results of the observation of the implementation of learning is fulfilled if the learning implementation reaches the minimum good category. The results of observations of learning feasibility are presented in Table 7.

Table 7. Recapitulation of percentage of learning implementation

\begin{tabular}{|c|l|l|l|l|}
\hline \multirow{2}{*}{$\begin{array}{l}\text { Learning } \\
\text { Meeting }\end{array}$} & \multicolumn{2}{|l|}{ Percentage } & \multicolumn{2}{l|}{ Mean Percentage } \\
\cline { 2 - 3 } & TA & SA & TA & SA \\
\hline 1 & 72 & 60 & 81 & 65 \\
\hline 2 & 76 & 64 & & \\
\hline 3 & 92 & 68 & & \\
\hline 4 & 84 & 68 & & \\
\hline
\end{tabular}

Note. TA (teacher activity), SA (Student's activity)

Based on observational data, the average percentage of implementation is more than $60 \%$, The average percentage of the implementation of learning in teacher activities is $81 \%$ in the very good category. The average percentage of the implementation of learning in student activities is $65 \%$ in the good category. Overall, based on the results of observations of the implementation of learning, it can be said that the learning set developed are practically used because they meet the minimum good category. In addition to using the learning feasibility observation sheet, the teacher's assessment of the lesson plans and student worksheets can be used as a guideline for determining practicality. Following are the results of the teacher's assessment of the lesson plan and student's worksheet. 
Table 8. Teacher assessment results

\begin{tabular}{|l|l|l|}
\hline Component & Score & Category \\
\hline Lesson Plan & 54 & Very Good \\
\hline $\begin{array}{l}\text { Student's } \\
\text { worksheet }\end{array}$ & 60 & Very Good \\
\hline
\end{tabular}

Based on the results of the teacher's assessment, the device is said to be practical if each component gets a minimum good category. With this result, the device is declared practical in terms of teacher assessment. Furthermore, practicality is viewed from the results of student assessments after learning using the tools developed. Student response after learning is known that 9 of 13 students gave very good responses, about 3 of 13 students gave good responses, about 1 of 13 students gave responses that were quite practical, and no students gave responses that were impractical or very impractical. Based on the student's response, the students responded positively to the learning set developed. This is in line with the research of Muthmainah et al [22] which states that students agree to implement learning with the STEM approach because students understand more easily the material to improve students' mathematical understanding in solving problems. Overall, seen from the learning feasibility sheet, teacher assessment, and student responses. It was concluded that the learning set developed were practical for use in mathematics learning.

The trial implementation ends with an assessment which is an aspect of the quality of effectiveness. The results of the learning tests which include students' mathematical connection abilities and student motivation are shown in Table 9 below.

Table 9. Study test results

\begin{tabular}{|l|l|l|}
\hline Aspect & Score & Category \\
\hline $\begin{array}{l}\text { Mathematics } \\
\text { connection ability }\end{array}$ & 14.2 & High \\
\hline student's motivation & 81.7 & Very High \\
\hline
\end{tabular}

Based on the table above, the mathematical connection ability and learning motivation fall into the high category and very high category. This means that the learning set developed are effectively used to develop mathematical connection skills and learning motivation.

The mathematical connection ability of students can be seen through three indicators. These indicators are connection between mathematical concepts (MC), the connection between mathematics and daily life (MDL), and the connection between mathematics and any field of science (MAF). The results of the mathematical connection ability tests are derived as follow.
Table 10. Mathematical connection test results

\begin{tabular}{|l|l|l|l|}
\hline Indicator & $\begin{array}{l}\text { Score } \\
\text { Maximun }\end{array}$ & N & $\%$ \\
\hline MC & 8 & 10 & 76.9 \\
\hline MDL & 6 & 8 & 61.5 \\
\hline MAF & 5 & 11 & 84.6 \\
\hline
\end{tabular}

Based on table 10, the MAF indicator gets the lowest percentage because of the 5 students who did not get the maximum score, their average error was unable to represent the results of their calculations. Students do not make conclusions so unanswered. The following is an example of student answers (Problem 2, Figure 2).

The example of the student's answer above shows that the student is able to count correctly, but the student does not represent the calculation result in real-world problems. So that the problem is not answered. This type of error is included in the Encoding error. This type of error is Error in interpreting mathematical solution in terms of the original context of the problem [23].

For another indicators, respondents in this study were able to answer correctly because the development of learning set with STEM PBL connected mathematics with Hooke's Law. So that the indicator of connecting mathematics with other fields science can be said to be successful with many students who are able to get a maximum score of 11 out of the total respondents 13 . The following is an example of a student worksheet developed (Figure 3).

Given information about Hooke's law, then the students prove the truth of the statement. It is in these proving steps that students learn to connect mathematical material with other fields. In addition, students will also be connected between concepts in mathematics during calculations and proof.

According to Table 9, the mathematical connection ability and student learning motivation are at a high level. If you look at the relationship between the two variables, it can be said to have a positive relationship. This can be seen in the following Figure 4 and Table 11. 


\section{Problem 2}

The accuracy of using catapults is affected by the tensile force and elasticity of the springs. The elasticity of the spring is influenced by the choice of material used. A student wants to make a catapult with attention to the elasticity of the material. The student uses two materials and each material is tested five times. The following is the experimental data to determine the elasticity of rubber using nipple rubber and inner tube rubber. By comparing the average elasticity values for each material, which material should be used in making catapults? * Explain your answer.

(Note: the higher the elasticity value, the better the material)

\begin{tabular}{|l|l|l|l|l|}
\hline \multirow{2}{*}{ Experiment } & Niple & \multicolumn{2}{|l|}{ Inner tube } \\
\cline { 2 - 6 } & F $(\mathrm{N})$ & increase in length $(\mathrm{m})$ & $\mathrm{F}(\mathrm{N})$ & increase in length $(\mathrm{m})$ \\
\hline 1 & 15 & 3 & 12 & 3 \\
\hline 2 & 37.1 & 7 & 23.6 & 4 \\
\hline 3 & 26 & 5 & 42 & 7 \\
\hline 4 & 11.2 & 2 & 28.5 & 5 \\
\hline 5 & 32 & 5 & 24.5 & 5 \\
\hline
\end{tabular}

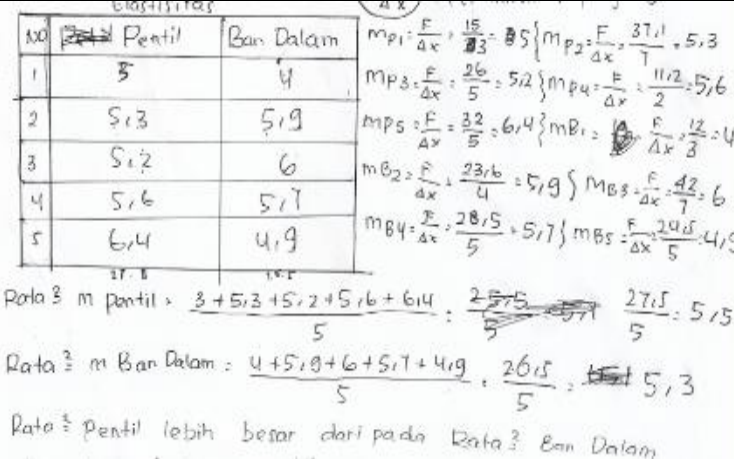

Figure 2 Example of student answers

\section{IMPROVE \\ Science Information \\ Hooke's law states that if the spring acts an external force, then the spring will increase in \\ length proportional to the magnitude of the force applied.}

IS THIS INFORMATION TRUE? LET'S PROVE!

Figure 3 Example of a student worksheet

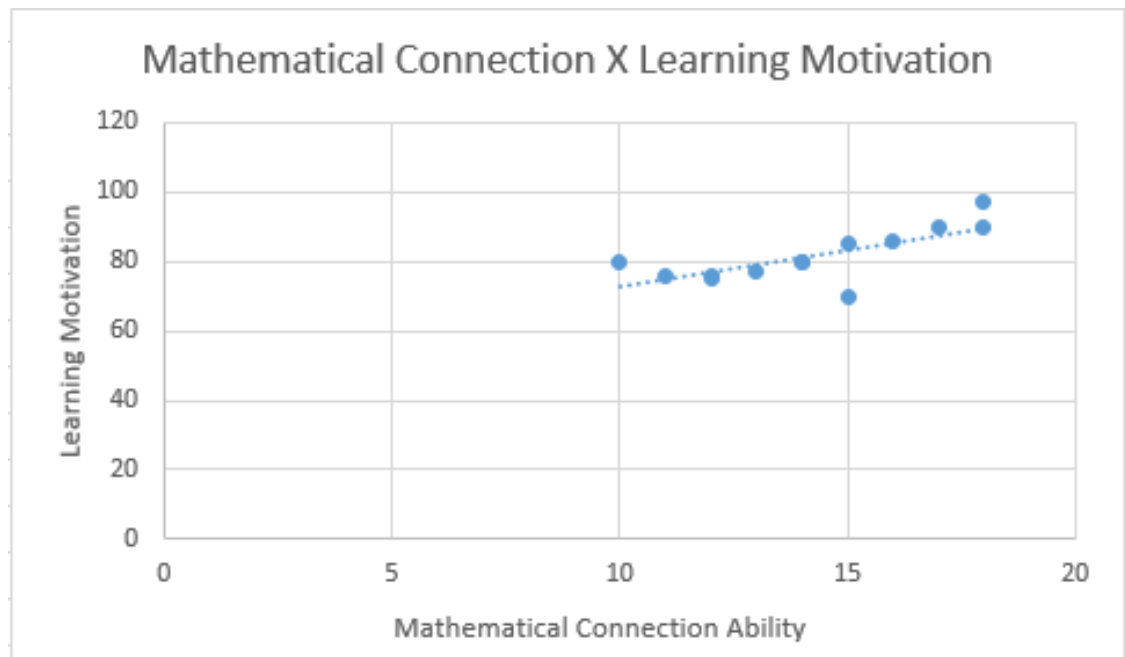

Figure 4 The relationship between mathematical connection ability and student's learning motivation 
Table 11 shows a significance value less than 0.05 , which means that the two variables have a correlation. The pearson correlation value of 0.74 indicates that there is a strong correlation between the two variables tested. The higher the student's learning motivation, the higher the mathematical connection ability and vice versa. [24]

Table 11. Correlation mathematical connection ability and student's learning motivation

\begin{tabular}{|l|l|l|}
\hline Pearson Correlation & Sig. & N \\
\hline 0.74 & 0.000 & 13 \\
\hline
\end{tabular}

Learning set with the STEM approach, the PBL learning model is proven to have a positive contribution to the connection skills and learning motivation of students. In line with Yulia's research [25] which states that the increase in the mathematical connection ability of students who get the Discovery Learning model with STEM-PjBL is better than students who get the expository method in the moderate and low learning resilience groups. This is because when learning STEM integrates mathematical problems with problems in other fields. In addition, the problems presented in PBL are not only mathematical problems but also real world problems. These two things are appropriate steps to facilitate the development of mathematical connection skills.

Both theoretically and empirically, STEM -PBL has been proven effective in developing students' thinking skills, especially in mathematics. Some of the results of previous research include obtaining empirical evidence regarding the effectiveness of STEM PBL in developing students 'higher-order thinking skills [26,27] which involves students' mathematical connection abilities. The effectiveness of STEM-PBL in improving mathematical connection skills is supported because of the characteristics of learning with the STEM approach that integrates mathematics with other fields and takes real problems. This is in line with the statement that STEM Education does not only integrate science, technology, engineering, and mathematics but an approach that applies real life [17]. This results in STEM having a positive effect on learning achievement.

\section{CONCLUSION}

The development of learning set in this study uses the Plomp model which includes three stages. In the first stage, the initial research includes needs analysis, namely material and situation analysis. The second stage is the development which includes product design and product manufacturing. At this stage, the initial product is obtained in the form of a learning implementation plan, books, and student activity sheets. The third stage, evaluation which includes the process of assessment (validation) and trials. The validation process is an assessment process by experts, namely two expert lecturers and one mathematics teacher. Based on this assessment, suggestions and input are obtained to be able to improve the product being developed. Furthermore, the trial process was carried out and the product of the development was obtained in the form of learning set with the STEM PBL model approach which was oriented towards the ability of mathematical connections and students' learning motivation on statistics material.

The quality of the products developed in this study is determined based on three aspects, namely aspects of validity, aspects of effectiveness, and aspects of practicality. Based on the results of the research and discussion, it can be concluded that the statistics learning set with the STEM-PBL approach are valid, effective, and practical. Therefore, the learning set developed is feasible to be used as a mathematics learning set. Some suggestions that the researcher can convey based on the results of this study, namely (1) the product of this development needs to be tested on a wider scale in the post-pandemic period (2) the products of this development should be applied to materials other than statistics and adjusted for STEM-PBL characteristics; (3) project selection on the development of STEM-PBL tools adapted to conditions in the field.

\section{ACKNOWLEDGMENTS}

We would like to thank Directorate of Research and Community Service, Ministry of Research and Technology of the Republic of Indonesia under grant No. 058/SP2H/LT/DRPM/2020.

\section{REFERENCES}

[1] Verma, A. K., Dickerson, D., \& McKinney, S. Engaging Students in STEM Careers with ProjectBased Learning-MarineTech Project. Technology and enginerring teacher, Vol 30, 2011, ISSN-21580502

[2] Shute, V. J. \& Becker, B. J. Innovative Assessment for the $21^{\text {st }}$ Century: Supporting Educational Needs. New York: Spinger, 2010.

[3] NCTM. Principles and Standards for School Mathematics. Reston VA: NCTM, 2000.

[4] Sugiman. Koneksi Matematika dalam Pembelajaran Matematika di Sekolah Menengah Pertama. Pythagoras, Vol 4 No 1, 2008, pp 56-66. https://doi.org/10.21831/pg.v4i1.687

[5] Kenedi, A. K., Helsa, Y., Ariani, Y., Zainil, M., \& Hendri, S. Mathematical Connection of Elementary School Students to Solve Mathematical Problems. Journal on Mathematics Education, Vol 10 No 1, 2019,

DOI: https://doi.org/10.22342/jme.10.1.5416.69-80 
[6] Wijayanti, Indra \& Abadi, Agus. Analysis of The Difficulty of VIII th Grade Junior High School Students in Circle Material Reviewed from The Mathematics Connection Ability. Journal of Physics: Conference Series. 1397. 012086. 2019, DOI: 10.1088/1742-6596/1397/1/012086.

[7] Kartikasari, A. \& Widjajanti, D., B. The Effectiveness of Problem-Based Learning Appproach Based on Multiple Intelligences in Terms of Student's Achievement, Mathematical Connection Ability, and Self Esteem. Jounal of Physics: Conference Series. 2017, doi:10.1088/1742-6596/812/1/012097

[8] Siregar, Nenta \& Surya, Edy. Analysis of Students' Junior High School Mathematical Connection Ability. International Journal of Sciences: Basic and Applied Research (IJSBAR). Vol 33. 2017, pp 309320.

[9] Sudirman, Cahyono, E. \& Kadir. Analisis Kemampuan Koneksi MatematisSiswa SMP Pesisir Ditinjau Dari Perbedaan Gender Jurnal Pembelajaran Berpikir Matematika, Vol 3 No. 2, 2018, pp $11-22$

[10] Saminanto \& Kartono. Analysis of Mathematical Connection Ability in Linear Equation with One Variable Based on Connectivity Theory. International Journal of Education and Research. Vol 3 No 4, 2015, ISSN: 2411-5681

[11] Ulya, I. F., Irawati, R. \& Maulana. Peningkatan Kemampuan Koneksi Matematis dan Motivasi Belajar Siswa Menggunakan Pendekatan Kontekstual. Jurnal Pena Ilmiah. Vol 1 No. 1, 2016, pp 121-130

[12] Lasmiyati \& Harta I., Pengembangan Modul Pembelajaran untuk Meningkatkan Pemahaman Konsep dan Minat SMP. PYTHAGORAS: Jurnal Penelitian Matematika. Vol 9 No 2. 2014 pp 161174.

[13] Dare, E. A., Ellis, J. A., Roehrig, G. H. Understanding science teachers' implementations of integrated STEM curricular units through a phenomenological multiple case study. International Journal of STEM Education Vol 5 No 4, 2018, pp 1-19

[14] Kelley, T. R., \& Knowles, J. G. A conceptual framework for integrated STEM education. International Journal of STEM Education, Vol 3 No 11, 2016, pp 1-11.

[15] Plomp, T. \& Nievenn, N. Educational Design Research. Enschede the Netherlands: SLO, 2013.
[16] Widoyoko, E. P. Teknik penyusunan instrumen penelitian. Yogyakarta: Pustaka Pelajar, 2012.

[17] Azwar, S. Penyusunan skala psikologi. Yogyakarta: Pustaka Pelajar, 2014

[18] Torlakson. T, Innovate: A Blueprint for Science, Technology, Engineering, and Mathematics in California Public Education. California: State Superintendent of Public Instruction, 2014.

[19] Blotnicky. A study of the correlation between STEM career knowledge, mathematics selfefficacy, career interests, and career activities on the likelihood of pursuing a STEM career among middle school students. International Journal of STEM Education. Vol 5 No. 22. 2018, https://doi.org/10.1186/s40594-018-0118-3

[20] Winkel, W. S. Psikologi pengajaran. Yogyakarta: Media Abadi. 2004.

[21] Hewitt, D. Understanding effective learning: strategies for the classroom. London, UK: McGraw-Hill, Open University Press. 2008.

[22] Fitriyani, W., \& Sugiman, S. Pengembangan perangkat pembelajaran teorema pythagoras dengan pendekatan ideal berbantuan geogebra. Jurnal Riset Pendidikan Matematika, Vol 1 No. 2, 2014, pp 269284, doi: https://doi.org/10.21831/jrpm.v1i2.2681

[23] Muthmainnah, Rahmah Johar, dan Anwar. Kemampuan Siswa SMP Membat Denah melalui Pendekatan Science, Technology, Engineering, Mathematics (STEM) Pada Materi Perbandingan. Jurnal Ilmiah Mahasiswa Pendidikan Matematika. Vol 4 No. 1, 2019, pp 73-80

[24] Yulia Nursari. PENINGKATAN KEMAMPUAN KONEKSI DAN BERPIKIR KREATIF MATEMATIS SISWA MELALUI MODEL DISCOVERY LEARNINGDAN PENDEKATAN SCIENCE TECHNOLOGI ENGINEERING MATHEMATIC (STEM) DITINJAU DARI TINGKAT KETANGGUHAN BELAJAR. Thesis(S2) thesis, Perpustakaan Pascasarjana. 2019

[25] Djidu, H., \& Jailani, J. Aktivitas pembelajaran matematika yang dapat melatih kemampuan berpikir tingkat tinggi siswa. PRISMA, Prosiding Seminar Nasional Matematika, Vol 1 No. 1, 2017, pp 312-321. Retrieved from https://journal.unnes.ac.id/sju/index.php/prisma/arti cle/view/21614.

[26] Djidu, H., \& Jailani, J. Developing problem based calculus learning model. Jurnal Kependidikan: Penelitian Inovasi Pembelajaran, Vol 2 No. 1, 2018, pp 68-84. 
[27] Becker, K., \& Park, K. 2011. Effects of integrative approaches among science, technology, engineering, and mathematics (STEM) subjects on students' learning: A preliminary meta-analysis. Journal of STEM Education, Vol 12, 2011, pp 2337 